\begin{tabular}{l} 
SPORTIVE: Journal of Physical Education, Sport and Recreation \\
Volume 5 Nomor 1 Maret 2021 \\
e-ISSN: 2597-7016 dan p-ISSN: $2595-4055$ \\
(c) (1) This work is licensed under a Creative Commons Attribution \\
\hline
\end{tabular}

\title{
Kontribusi Kekuatan Lengan, Kelentukan Dan Keseimbangan Terhadap Kemampuan Roll Ke Depan Pada Senam Lantai Siswa SMKN I Makassar
}

\section{Ichsani $^{1 *}$, Sulaeman ${ }^{2}$, Andi Yulianti ${ }^{3}$}

\section{Keywords :}

Kekuatan Lengan,

Kelentukan, Keseimbangan,

Roll Depan, Senam

\section{Corespondensi Author}

1,2,3 Universitas Negeri

Makassar,

ichsani@unm.ac.id

sulaemanfik@unm.ac.id

Andiyulianti27@gmail.com

\section{Article History}

Received: tgl-bln-thn;

Reviewed: tgl-bln-thn;

Accepted: tgl-bln-thn;

Published: tgl-bln-thn

\begin{abstract}
The purpose of this study was to determine the contribution of arm strength, flexibility and balance to the forward roll ability of the students of SMK Negeri 1 Makassar. This type of research is a quantitative descriptive study. The sample in this study were students of SMK Negeri 1 Makassar who were selected through random sampling technique. The results of the regression analysis of arm strength on the forward roll ability in floor exercise contributed $36 \%$. The results of the flexibility regression analysis on the forward roll ability of the students of SMKN I Makassar contributed $48.50 \%$. The results of the balance regression analysis on the ability to roll forward on the floor gymnastics of SMKN I Makassar students contributed $26.50 \%$. And the results of the regression analysis of arm strength, flexibility, and balance on the ability to roll forward on the floor gymnastics students of SMKN I Makassar contributed $57.50 \%$.
\end{abstract}

\footnotetext{
ABSTRAK

Tujuan dari penelitian ini adalah untuk mengetahui kontribusi kekuatan lengan, kelentukan dan keseimbangan terhadap kemampuan roll ke depan pada senam lantai siswa SMK Negeri 1 Makassar. Jenis penelitian ini adalah penelitian deskriptif kuantitatif. Sampel pada penelitian ini adalah siswa SMK Negeri 1 Makassar yang dipilih melalui tehnik random sampling. Hasil Analisis regresi kekuatan lengan terhadap kemampuan roll ke depan pada senam lantai memberikan kontribusi sebesar 36\%. Hasil snalisis regresi kelentukan terhadap kemampuan roll ke depan siswa SMKN I Makassar memberikan kontribusi sebesar 48,50\% . Hasil analisis regresi keseimbangan terhadap kemampuan roll ke depan pada senam lantai siswa SMKN I Makassar memberikan kontribusi sebesar 26,50\%. Dan hasil analisis regresi kekuatan lengan, kelentukan, dan keseimbangan terhadap kemampuan roll ke depan pada senam lantai siswa SMKN I Makassar memberikan kontribusi sebesar $57,50 \%$.
} 



\section{PENDAHULUAN}

Pendidikan merupakan masalah fundamental bagi suatu bangsa. Suatu bangsa akan maju apabila memiliki sistem pendidikan yang baik dan dapat dilaksanakan di lapangan, sekaligus dapat menyentuh seluruh lapisan masyarakat. Salah satu usaha pemerintah untuk mewujudkan tujuan pendidikan adalah dengan diberikannya mata pelajaran pendidikan jasmani olahraga dan kesehatan di setiap sekolah.

Pendidikan jasmani olahraga dan kesehatan merupakan salah satu usaha yang menggunakan jasmani sebagai media dalam rangka pembentukan manusia. Salah satu bahasan pokok dalam pendidikan jasmani olahraga dan kesehatan adalah senam ketangkasan atau senam lantai. Senam ketangkasan atau senam lantai adalah bentukbentuk gerakan yang terdapat dalam olahraga senam, sebagai perwujudan dari dunia gerak dan penghayatan raga yang sama halnya dengan bentuk atau gerakan olahraga lainnya. Proses pembelajaran Pendidikan jasmani olahraga dan kesehatan yang tercantum dalam kurikulum merupakan bagian integral dari sistem pendidikan yang pada hakikatnya untuk membentuk dan mengembangkan kepribadian serta kemampuan siswa. Salah satu usaha yang diberikan untuk mencapai tujuan di atas adalah memasukkan mata pelajaran penjas dalam kurikulum pembelajaran penjas dengan materi senam lantai disemua jenjang pendidikan.

Senam lantai digolongkan dalam senam ketangkasan, diperagakan di atas lantai yang beralaskan matraks. Menurut (Pinayungan, 1987) bahwa : Senam lantai adalah senam dasar, yang latihan-latihannya dapat dilakaukan untuk keterampilan perorangan secara sendiri-sendiri, berkawan, ataupun berkelompok. Pada umumnya senam ini dilakukan dengan dua cara yaitu : 1. Senam lantai tanpa alat, dan 2. Senam lantai pakai alat.

Senam lantai yang diajarkan di sekolah merupakan bentuk-bentuk gerakan yang terdapat dalam olahraga senam, sebagai perwujudan dari dunia gerak dan penghayatan raga yang sama halnya dengan bentuk olahraga lainnya. Untuk mencapai tujuan tersebut senam lantai atau senam ketangkasan juga mengembangkan cirinya ke luar melalui aktifitas jasmani. Selain untuk mengembangkan alat-alat tubuh dan fungsinya, juga untuk perkembangan kepribadian yang bulat dalam kehidupannya. De ngan demikian senam ketangkasan atau senam lantai tidak bisa berdiri sendiri dari usaha-usaha pendidikan jasmani khususnya dan pendidikan secara keseluruhan, melainkan harus berjalan seirama dengan pendidikan jasmani lainnya. Mempelajari bentuk-bentuik gerakan merupakan syarat mutlak untuk dapat bergerak dengan baik dan benar, serta dapat berprestasi secara optimal. Mengembangkan kemampuan dengan mempelajari bentuk-bentuk senam ketangkasan untuk mencapai prestasi, membutuhkan keuletan, konsentrasi, kewaspadaan, keberanian, dan percaya diri sendiri. Pokok bahasan senam lantai atau senam ketangkasan yang diberikan pada siswa bukanlah semata-mata untuk pencapaian prestasi yang terukur saja, tetapi demi pembentukan sikap kepribadian siswa dalam usaha mencapai prestasi maksimal.

Untuk meningkatkan kondisi fisik secara keseluruhan, maka kekuatan otot merupakan salah satu faktor utama, sebagaimana yang dikemukakan oleh (Harsono, 1988b), sebagai berikut : Pertama, oleh karena kekuatan merupakan daya penggerak setiap aktivitas fisik. Kedua oleh karena kekuatan memegang peranan penting dalam melindungi atlet/orang dari kemungkinan cedera. Ketiga oleh karena dengan kekuatan, atlet akan dapat lari lebih cepat, melempar atau menendang lebih jauh dan lebih efisien, memukul lebih keras, demikian pula dapat membantu memperkuat stabilitas sendi-sendi.

Pada dasarnya semua cabang olahraga membutuhkan unsur kelentukan (fleksibilitas), karena kelentukan menunjukan kualitas yang memungkinkan suatu segmen bergerak semaksimal menurut kemungkinan bergerak. Kualitas itu kemungkinan otot-otot atau sekelompok otot untuk memanjang dan memendek serta memanfaatkan sendi-sendi secara maksimal. Berdasarkan hal tersebut, maka setiap cabang olahraga mempunyai persamaan mengenai pentingnya unsur fleksibilitas dalam penampilan yang optimal. (Harsono, 1988a) memberikan definisi sebagai

Mberikut (Kódsabènth melakukan gerakan dalam ruang gerak sendi, kecuali oleh ruang gerak sendi, kelentukan juga ditentukan oleh elastitas tidaknya otot-otot, tendo dan ligament".

Keseimbangan merupakan kemampuan sesorang mempertahankan sistem tubuh baik dalam posisi statis maupun lebih-lebih dalam posisi gerak dinamis yang mana keseimbangan juga merupakan hal yang sangat penting di dalam melakukan suatu gerakan karena dengan keseimbangan yang baik, maka seseorang mampu mengkoordinasikan gerakan-gerakan dan dalam beberapa ketangkasan unsur kelincahan. Menurut (Sajoto, 1988) 
Keseimbangan atau balance adalah kemampuan seseorang mengendalikan organ-organ syaraf ototnya selama melakukan gerakan-gerakan yang cepat dengan perubahan letak titik berat badan yang secara pula baik dalam keadaan statis maupun lebih-lebih dalam keadaan gerak dinamis. Sedangkan menurut Menurut Yahya dalam (Sulaeman et al., 2019) "Keseimbangan atau balance diartikan sebagai kemampuan untuk mempertahankan sistem neuromuscular tubuh dalam kondisi statis atau mengontrol sistem neuromuscular dalam suatu posisi atau sikap yang efisien sementara bergerak".

Di sekolah-sekolah khususnya SMKN I Makassar, senam lantai diajarkan dengan gerakan-gerakan yang sederhana seperti roll ke depan. Siswa belum diajarkan pada gerakan yang sangat kompleks, karena dapat membahayakan siswa. Para guru penjas di sekolah mengajarkan senam lantai tanpa mempertimbangkan pembentukan kekuatan, kelentukan dan keseimbangan dari siswasiswinya. Dalam proses belajar senam lantai, disamping teknik gerakan perlu ditunjang oleh komponen-komponen fisik yang kompleks. Tidak semua unsur-unsur kemampuan gerak ini berpengaruh pada suatu gerakan tertentu yang dapat diprediksikan sebagai komponen kesegaran fisik yang ada hubungannya dengan gerakan roll ke depan pada senam lantai. Roll ke depan adalah berguling yang dilakukan ke depan dengan bulat. Jadi unsur-unsur tertentu yang dapat diprediksikan sebagai komponen kesegaran fisik yang ada kontribusinya dengan gerakan roll ke depan pada senan lantai. Komponen-komponen kesegaran fisik yang dimaksud antara lain: kekuatan lengan, kelentukan, dan keseimbangan.

Beranjak dari penjelasan dengan permasalahan yang telah dikemukakan, maka perlu adanya pembuktian secara ilmiah dengan melalui penelitian. Untuk itu peneliti melakukan penelitian dengan judul: "Kontribusi kekuatan lengan, kelentukan dan keseimbangan terhadap kemampuan roll ke depan pada senam lantai siswa SMKN I Makassar".
Jenis penelitian ini merupakan deskriptif kuantitatif. Penelitian kuantitatif merupakan penelitian yang menggunakan dengan angkaangka dan analisis menggunakan data statistik. Adapun variabel bebas pada penelitian ini adalah kekuatan lengan, kelentukan dan keseimbangan. Sedangkan variabel terikat adalah kemampuan roll ke depan pada senam lantai.

Penelitian dilaksanakan di SMK Negeri Makassar dimana populasi adalah seluruh siswa SMK Negeri 1 Makassar. Sampel pada penelitian ini adalah 40 orang siswa SMK Negeri 1 Makassar dengan tehnik pemilihan sampel yaitu random sampling.

Tehnik pengambilan data pada penelitian ini menggunakan beberapa tes yaitu tes kekuatan lengan, tes kelentukan togok, tes keseimbangan dan tes kemampuan roll ke depan pada senam lantai (Halim \& Anwar, 2018). Sedangkan tehnik analisis data akan dianalisa secara deskriptif dan inferensial menggunakan aplikasi pengolah data SPSS dengan taraf signifikan $95 \%$.

\section{HASIL DAN PEMBAHASAN}

\section{A. Hasil}

Setelah melewati uji prasyarat yaitu uji normalitas, maka selanjutnya adalah uji hipotesis. Hipotesis yang diajukan dalam penelitian ini perlu diuji dan dibuktikan melalui data empiris yang diperoleh dilapangan melalui tes dan pengukuran terhadap seluruh variabel yang diteliti. Karena data penelitian ini mengikuti sebaran normal, maka untuk menguji hipotesis penelitian ini digunakan analisis statistik parametrik dengan menggunakan teknik regresi.

a. Analisis regresi kekuatan lengan terhadap kemampuan roll ke depan pada senam lantai.

Untuk menguji kebenaran hipotesis tentang ada tidaknya kontribusi yang signifikan kekuatan lengan terhadap kemampuan roll ke depan pada senam lantai siswa SMKN I Makassar, dilakukan analisis regresi. Untuk lebih jelasnya dapat dilihat pada tabel 1 .

\section{METODE}

Tabel 1. Rangkuman hasil uji regresi data kekuatan lengan terhadap kemampuan roll ke depan pada senam lantai siswa SMKN I Makassar 


\begin{tabular}{|l|c|c|c|c|c|}
\hline \multicolumn{1}{|c|}{ Variabel } & $\mathrm{N}$ & $\beta$ & to & $\mathrm{P}_{\text {value }}$ & Keterangan \\
\hline $\begin{array}{l}\text { Kekuatan lengan }\left(\mathrm{X}_{1}\right) \\
\text { Kemampuan roll ke depan }(\mathrm{Y})\end{array}$ & 40 & 0,600 & 4,626 & 0,000 & Signifikan \\
\hline
\end{tabular}

Berdasarkan tabel 1 di atas, terlihat bahwa hasil uji analisis koefisien regresi dengan menggunakan uji regresi dikemukakan sebagai berikut; nilai $\beta$ hitung diperoleh $=0,600\left(\mathrm{P}_{\text {value }}<\right.$ $\alpha 0,05)$ berarti ada kontribusi yang signifikan kekuatan lengan terhadap kemampuan roll ke depan pada senam lantai siswa SMKN I Makassar. b. Analisis regresi kelentukan terhadap kemampuan roll ke depan siswa SMK 1 Makassar.

Untuk menguji kebenaran hipotesis tentang ada tidaknya kontribusi yang signifikan kelentukan terhadap kemampuan roll ke depan pada senam lantai siswa SMKN I Makassar, dilakukan analisis regresi. Untuk lebih jelasnya dapat dilihat pada tabel 2 .

Tabel 2. Rangkuman hasil uji regresi data kelentukan terhadap kemampuan roll ke depan pada senam lantai siswa SMKN I Makassar

\begin{tabular}{|l|l|l|l|l|l|}
\hline Variabel & $\mathrm{N}$ & $\beta$ & to & $\mathrm{P}_{\text {value }}$ & Keterangan \\
\hline $\begin{array}{l}\text { Kelentukan }\left(\mathrm{X}_{2}\right) \\
\text { Kemampuan roll ke depan }(\mathrm{Y})\end{array}$ & 40 & 0,677 & 5,669 & 0,000 & Signifikan \\
\hline
\end{tabular}

Berdasarkan tabel 2 di atas, terlihat bahwa hasil uji analisis koefisien regresi dengan menggunakan uji regresi dikemukakan sebagai berikut; nilai $\beta$ hitung diperoleh $=0,677\left(\mathrm{P}_{\text {value }}<\right.$ $\alpha 0,05)$ berarti ada kontribusi yang signifikan kelentukan terhadap kemampuan roll ke depan pada senam lantai siswa SMKN I Makassar. c. Analisis regresi keseimbangan terhadap kemampuan roll ke depan pada senam lantai siswa SMKN I Makassar.

Untuk menguji kebenaran hipotesis tentang ada tidaknya kontribusi yang signifikan keseimbangan terhadap kemampuan roll ke depan pada senam lantai siswa SMKN I Makassar, dilakukan analisis regresi. Untuk lebih jelasnya dapat dilihat pada tabel 3 . 
Tabel 3. Rangkuman hasil uji regresi data keseimbangan terhadap kemampuan roll ke depan pada senam lantai siswa SMKN I Makassar

\begin{tabular}{|l|c|c|c|c|c|}
\hline \multicolumn{1}{|c|}{ Variabel } & $\mathrm{N}$ & $\beta$ & to & $\mathrm{P}_{\text {value }}$ & Keterangan \\
\hline $\begin{array}{l}\text { Keseimbangan }\left(\mathrm{X}_{3}\right) \\
\text { Kemampuan roll ke depan }(\mathrm{Y})\end{array}$ & 40 & 0,515 & 3,705 & 0,000 & Signifikan \\
\hline
\end{tabular}

Berdasarkan tabel 3 di atas, terlihat bahwa hasil uji analisis koefisien regresi dengan menggunakan uji regresi dikemukakan sebagai berikut; nilai $\beta$ hitung $(\beta)$ diperoleh $=0,515$ (Pvalue $<0,05)$ berarti ada kontribusi yang signifikan keseimbangan terhadap kemampuan roll ke depan pada senam lantai siswa SMKN I Makassar.

d. Analisis regresi kekuatan lengan, kelentukan, dan keseimbangan terhadap kemampuan roll ke depan pada senam lantai siswa SMKN I Makassar.

Untuk mengetahui besarnya kontribusi secara bersama-sama kekuatan lengan, kelentukan, dan keseimbangan terhadap kemampuan roll ke depan pada senam lantai siswa SMKN I Makassar, maka perlu dianalisis dengan menggunakan analisis regresi. Untuk lebih jelasnya, maka rangkuman hasil analisis regresi dapat dilihat pada tabel 4 .

Tabel 4. Rangkuman hasil uji regresi data kekuatan lengan, kelentukan, dan keseimbangan terhadap kemampuan roll ke depan pada senam lantai siswa SMKN I Makassar

\begin{tabular}{|l|c|c|c|c|c|}
\hline \multicolumn{1}{|c|}{ Variabel } & $\mathrm{R}$ & $\mathrm{R}^{2}$ & $\mathrm{~F}$ & $\mathrm{P}_{\text {value }}$ & Keterangan \\
\hline $\begin{array}{l}\text { Kekuatan lengan }\left(\mathrm{X}_{1}\right), \\
\begin{array}{l}\text { Kelentukan }\left(\mathrm{X}_{2}\right) \text { dan } \\
\text { Keseimbangan }\left(\mathrm{X}_{3}\right)\end{array}\end{array}$ & 0,758 & 0,575 & 16,256 & 0,000 & Signifikan \\
Kemampuan roll ke depan $(\mathrm{Y})$ & & & & & \\
\hline
\end{tabular}

Berdasarkan tabel 4 di atas, terlihat bahwa hasil uji analisis koefisien regresi ganda dengan menggunakan uji-r regresi dikemukakan sebagai berikut; nilai $\mathrm{r}$ hitung $(\mathrm{R})$ diperoleh sebesar 0,758 , nilai koefisien determinasi Rsquare (R2) diperoleh sebesar 0,575 (Pvalue < $0,05)$ setelah dilakukan uji signifikan atau keberartian regresi ganda dengan menggunakan uji $\mathrm{F}$ regresi diperoleh $\mathrm{F}$ hitung sebesar 16,256 (Pvalue < 0,05), maka H0 ditolak dan H1 diterima, berarti ada kontribusi yang signifikan antara kekuatan lengan, kelentukan, dan keseimbangan terhadap kemampuan roll ke depan pada senam lantai siswa SMKN I Makassar.

\section{B. Pembahasan}

Hasil-hasil analisis regresi dalam hipotesis perlu dikaji lebih lanjut dengan memberikan interpretasi keterkaitan antara hasil analisis yang dicapai dengan teori-teori yang mendasari penelitian ini. Penjelasan ini diperlukan agar dapat diketahui kesesuaian teori-teori yang dikemukakan dengan hasil penelitian yang dicapai. Untuk mengambil kesimpulan penelitian yang sesuai dengan tujuan penelitian, maka hasil analisis data yang perlu dibahas sesuai dengan teoriteoi yang mendasarinya. Adapun pembahasan yang dimaksud adalah sebagai berikut: 
1. Pengujian hipotesis menunjukkan, bahwa dari hasil analisis data diperoleh bahwa ada kontribusi yang signifikan kekuatan lengan terhadap kemampuan roll ke depan pada senam lantai siswa SMKN I Makassar. Apabila hasil penelitian ini dikaitkan dengan teori dan kerangka pikir yang mendasarinya, maka pada dasarnya hasil penelitian ini mendukung dan memperkuat teori dan hasil-hasil penelitian terdahulu bahwa kekuatan merupakan kemampuan otot-otot mengeluarkan tenaga untuk menggerakkan sesuatu. Kekuatan otot lengan diperlukan oleh pesenam untuk menahan atau menopang anggota tubuhnya dengan kuat saat melakukan gerakan roll ke depan. Hal ini mengandung makna bahwa, apabila nilai kekuatan lengan tergolong baik, maka akan diikuti dengan nilai kemampuan roll ke depan pada senam lantai yang baik pula. Begitu pula sebaliknya, apabila nilai kekuatan lengan yang kurang baik, maka akan diikuti dengan nilai kemampuan roll ke depan yang kurang baik pula.

2. Pengujian hipotesis menunjukkan, bahwa dari hasil analisis data diperoleh bahwa ada kontribusi yang signifikan antara kelentukan terhadap kemampuan roll ke depan siswa SMKN I Makassar. Apabila hasil penelitian ini dikaitkan dengan teori dan kerangka pikir yang mendasarinya, maka pada dasarnya hasil penelitian ini mendukung dan memperkuat teori dan hasil-hasil penelitian terdahulu bahwa kelentukan merupakan kemampuan untuk melakukan gerakan dalam ruang gerak sendi, kecuali oleh ruang gerak sendi, kelentukan juga ditentukan oleh elastitas tidaknya otot-otot, tendo dan ligament. Untuk itu pergerakan yang dilakukan dalam setiap aktifitas olahraga membutuhkan kelentukan togok dalam menampilkan pola gerakan yang lebih luas. Artinya kelentukan merupakan kemampuan seseorang melakukan gerakan dengan pengukuran yang seluas-luasnya sehingga gaya yang diarahkan akan lebih besar pada saat melakukan gerakan roll depan dengan baik dan sempurna. Hal ini mengandung makna bahwa, apabila nilai keseimbangan tergolong baik, maka akan diikuti dengan nilai kemampuan passsing bawah pada permainan sepakbola yang baik pula. Begitu pula sebaliknya, apabila nilai keseimbangan yang kurang baik, maka akan diikuti dengan nilai kemampuan roll ke depan yang kurang baik pula.

3. Pengujian hipotesis menunjukkan, bahwa dari hasil analisis data diperoleh bahwa ada kontribusi yang signifikan antara keseimbangan terhadap kemampuan roll ke depan siswa SMKN I Makassar. Apabila hasil penelitian ini dikaitkan dengan teori dan kerangka pikir yang mendasarinya, maka pada dasarnya hasil penelitian ini mendukung dan memperkuat teori dan hasil-hasil penelitian terdahulu bahwa keseimbangan atau balance merupakan kemampuan seseorang mengendalikan organ-organ syaraf ototnya selama melakukan gerakan-gerakan yang cepat dengan perubahan letak titik berat badan yang secara pula baik dalam keadaan statis maupun lebih-lebih dalam keadaan gerak dinamis. Pada pelaksanaan gerakan roll ke depan sedapatnya ia dapat bergerak dengan stabil dan mengendalikan posisi tubuhnya dengan tepat. Artinya ketika atlet bergerak atau bertindak secepatnya pula dapat menimbang untung ruginya apabila menempatkan posisi badannya yang tidak seimbang dibandingkan dengan posisi badan yang lebih seimbang guna lebih mengefesienkan gerakan. Hal ini mengandung makna bahwa, apabila nilai keseimbangan tergolong baik, maka akan diikuti dengan nilai kemampuan roll ke depan pada senam lantai yang baik pula. Begitu pula sebaliknya, apabila nilai keseimbangan yang kurang baik, maka akan diikuti dengan nilai kemampuan roll ke depan yang kurang baik pula.

4. Pengujian hipotesis menunjukkan, bahwa dari hasil analisis data diperoleh bahwa ada kontribusi yang signifikan kekuatan lengan, kelentukan, dan keseimbangan terhadap kemampuan roll ke depan pada senam lantai siswa SMKN I Makassar. Apabila hasil penelitian ini dikaitkan dengan teori dan kerangka pikir yang mendasarinya, maka pada dasarnya hasil penelitian ini mendukung dan memperkuat teori dan hasil-hasil penelitian terdahulu yang ada. Hal ini mengandung makna bahwa, apabila nilai kekuatan lengan, kelentukan, dan keseimbangan, tergolong baik, maka akan diikuti dengan nilai kemampuan roll ke depan pada senam lantai yang baik pula. Begitu pula sebaliknya, apabila nilai kekuatan lengan, kelentukan, dan 
keseimbangan yang kurang baik, maka akan diikuti dengan nilai kemampuan roll ke depan yang kurang baik pula.

\section{SIMPULAN DAN SARAN}

\section{Kesimpulan}

Adapun kesimpulan dalam penelitian ini adalah sebagai berikut:

1. Ada kontribusi yang signifikan kekuatan lengan terhadap kemampuan roll ke depan pada senam lantai siswa SMKN I Makassar.

2. Ada kontribusi yang signifikan kelentukan terhadap kemampuan roll ke depan pada senam lantai siswa SMKN I Makassar.

3. Ada kontribusi yang signifikan keseimbangan terhadap kemampuan roll ke depan pada senam lantai siswa SMKN I Makassar.

4. Ada kontribusi yang signifikan kekuatan lengan, kelentukan, dan keseimbangan secara bersama-sama terhadap kemampuan roll ke depan pada senam lantai siswa SMKN I Makassar.

\section{Saran}

Adapun saran yang dikemukakan dalam penelitian ini adalah sebagai berikut:

1. Bagi para guru penjas, pembina maupun pelatih olahraga senam lantai, bahwa kiranya dalam upaya untuk meningkatkan kemampuan roll ke depan pada senam lantai bagi siswa atau atlet yang dibina, hendaknya perlu memperhatikan unsur kemampuan fisik yang dapat menunjang, seperti kekuatan lengan, kelentukan, dan keseimbangan.

2. Didalam memilih siswa atau bibit atlet senam lantai hendaknya dipilih yang memiliki kekuatan lengan, kelentukan, dan keseimbangan, dan faktor-faktor lain yang dapat meningkatkan prestasi atlet.

3. Untuk menjadikan sebagai bahan perbandingan atau masukan bagi pemerintah daerah dan lembaga keolahragaan seperti KONI dan Pencab Persani Kota Makassar.

4. Dapat dimanfaatkan sebagai bahan perbandingan bagi peneliti atau mahasiswa lain yang berminat untuk mengadakan penelitian lebih lanjut dengan memperhatikan berbagai sudut pandang masalah yang lebih luas.

\section{DAFTAR RUJUKAN}

Halim, N. ihsan, \& Anwar, K. (2018). Tes dan Pengukuran dalam bidang keolahragaan (Badan Penerbit UNM (ed.)).

Harsono. (1988a). Coaching dan AspekAspek Psikologi dalam Coaching. Jakarta.

Harsono. (1988b). Perkembangan Kondisi Fisik. jakarta.

Kosasi, E. (1985). Olahraga dan Kesehatan. Tiga Serangkai.

Pinayungan. (1987). Senam UntNo Titleuk Sekolah Dasar. Dirjen Pendidikan Dasar dan Menengah, Depdikbud.

Sajoto, M. (1988). Pembinaan Kondisi Fisik Dalam Bidang Olahraga. Depdikbud Dirjen Dikti.

Sulaeman, S., Rahman, A., \& Mappanyukki, A. A. (2019). Analisis Kelentukan, Keseimbangan Dan Koordinasi Mata Kaki Terhadap Ketepatan Tendangan Pada Permainan Sepakbola. SPORTIVE: Journal Of Physical Education, Sport and Recreation, 3(1), 70. https://doi.org/10.26858/sportive.v3i1.1 6862 